\title{
Potential relationships of selected abiotic variables, chemical elements and stand characteristics with soil organic carbon in spruce and beech
}

\section{stands}

\author{
Marián Horváth ${ }^{(1)}$, \\ Petra Hanáková Bečvářová (1), \\ Bořivoj Šarapatka (1), \\ Ondřej Vencálek ${ }^{(2)}$, \\ Václav Zouhar ${ }^{(3)}$
}

(1) Department of Ecology and Environmental Sciences, Faculty of Science, Palacký University Olomouc, Šlechtitelu 241/27, 783 71 Olomouc - Holice (Czech Republic); (2) Department of Mathematical Analysis and Ap plications of Mathematics, Faculty of Science, Palacký University Olomouc 17, listopadu 12, 77146 Olomouc (Czech Repub(ic); (3) Forest Management Institute, Brandýs nad Labem, Branch Brno, Vrázova 1, 61600 Brno - Zabovresky (Czech Republic)

@ Bořivoj Šarapatka

(borivoj.sarapatka@upol.cz)

Received: Sep 17, 2020 - Accepted: May 11, 2021

Citation: Horváth $\mathrm{M}$, Bečvářová $\mathrm{PH}$ Šarapatka B, Vencálek O, Zouhar V (2021). Potential relationships of selected abiotic variables, chemical elements and stand characteristics with soil organic carbon in spruce and beech stands. iForest 14: 320 328. - doi: 10.3832/ifor3654-014 [online 2021-07-09]

Communicated by: Marco Borghetti

Increasing attention is given to carbon sequestration in forest soil with regard to climate change and the mitigation of its impacts; therefore, it is very important to know which parameters and variables could influence carbon sequestration and throw light on their relationships. The aim of this study is to assess the role of abiotic variables, chemical elements and stand parameters in soil carbon sequestration, and clarify which of these could affect soil organic carbon (SOC) content in the surface mineral horizon in Norway spruce and European beech stands in the Czech Republic. We analyzed 81 monitoring plots within pure and mixed stands of spruce and beech with different degrees of forest naturalness. In each monitoring plot, SOC content, chemical elements (content of bound forms of oxides: tFe, tAl, tCa, tMg, tK, tMn, tP, tN) and related variables $(\mathrm{BS}, \mathrm{pH}, \mathrm{C} / \mathrm{N})$ were measured. The effect of these variables, in cluding abiotic variables (elevation, temperature, precipitation, duration of growing season and soil group) on SOC content was tested, and differences between represented stands (natural vs. unnatural, pure vs. mixed, spruce vs. beech) were analyzed. The results showed that elevation has a positive relationship to SOC content. Of the studied chemical elements and related variables, only $\mathrm{tN}$ content was significantly related to SOC content. A positive relationship was also demonstrated between forest naturalness and SOC content. The highest SOC and $\mathrm{tN}$ contents were observed in pure natural Norway spruce stands, which likely play a very important role in SOC sequestration. In the context of the current issue of unnatural Norway spruce stands in the Czech Republic, a higher SOC content was found in mixed natural European beech stands than in either pure or mixed unnatural Norway spruce stands. Therefore, replacing the unnatural Norway spruce stands in the study area with mixed natural European beech stands could represent a viable alternative to current forest management in terms of soil carbon sequestration, especially in the context of global climate change and spruce dieback.

Keywords: Soil Organic Carbon (SOC), Carbon Sequestration, Forest Soil, Norway Spruce, European Beech, Chemical Elements

\section{Introduction}

The role of forest ecosystems in the global carbon cycle, and subsequently in carbon sequestration, is clear and fairly well documented (Jandl et al. 2007, Ciais et al. 2008, Lorenz \& Lal 2010). The attention of most authors focuses on the potential for carbon sequestration in soils beneath various tree species (Vesterdal et al. 2013). Coniferous and deciduous forest stands (mainly spruce and beech) are usually compared. Many studies reported that conifers in general, and especially Norway spruce, contain higher SOC stock in the mineral horizon than other tree species (Vesterdal et al. 2013, Andivia Muñoz et al. 2015, Kern et al. 2016, Jonard et al. 2017).

Norway spruce (Picea abies [L.] H. Karst.) and European beech (Fagus sylvatica L.) are the most common tree species in the Czech Republic. Norway spruce is the dominant tree species with a share of $50 \%$, but in natural tree species composition its share should not exceed $11 \%$ (Cermák et al.
2017, Czech Ministry of Agriculture 2018). European beech is the dominant broadleaf tree species; its current share is around $8 \%$, but historically it was about $40 \%$ and that should also be its natural share in forests (Czech Ministry of Agriculture 2018, Standovár \& Kenderes 2003).

The present proportion of Norway spruce is significantly higher than its original natural range, not only in the Czech Republic but throughout Central Europe. Klimo et al. (2000) stated that its present distribution originates from the reforestation of extensive clear-cut areas carried out in the late $18^{\text {th }}$ and early $19^{\text {th }}$ centuries in the zone of fir/beech and beech plant communities as well as in the oak/beech and oak zones. The spruce monoculture distribution is also similar in other Central European countries. In connection with silviculture of economically advantageous tree species, it became common for Norway spruce stands (the socalled secondary spruce forests) to be grown intensively (cultivated) also on un- 
suitable and primarily unnatural sites (Ammer et al. 2008, Löf et al. 2010). Growing spruce forests on unnatural sites meant forcing out and removing the site-natural tree species, often the beech, but also other tree species.

Currently, forest managers in the Czech Republic are struggling with the problem of spruce monocultures grown on unnatural habitats in the context of global climate change and the associated dieback of spruce. According to regional scenarios for the predicted impact of climate change for the Czech Republic in 2030 (Čermák et al. 2004), it is possible to assume that the most affected stands will be Norway spruce stands in the elevation range of 400-600 $\mathrm{m}$ a.s.l. In this range, it is expected that spruce forests will almost completely disappear. The occurrence of Norway spruce will be limited to higher elevations above $600 \mathrm{~m}$ a.s.l. (mountain forests), i.e., locations where this species is naturally occurring and dominant (Čermák et al. 2004, Čermák \& Holuša 2010, Hlásný et al. 2011). Therefore, it is necessary to find a suitable stand composition of natural tree species which could replace these unnatural stands, ensuring at the same time a comparable carbon sequestration.

The main aim of this study was to assess the relationship or potential influence of abiotic variables (elevation, temperature, precipitation, duration of growing season and soil group), chemical elements (content of bound forms of oxides of $\mathrm{Fe}, \mathrm{Al}, \mathrm{Ca}$, $\mathrm{Mg}, \mathrm{K}, \mathrm{Mn}, \mathrm{P}$ and $\mathrm{N}$ ) and related variables (base saturation, $\mathrm{pH}$, and $\mathrm{C} / \mathrm{N}$ ratio) on $\mathrm{SOC}$ content in the surface mineral horizon in stands of Norway spruce and European beech. Due to the current problem of unnatural spruce stands in the Czech Republic, our objectives were to assess whether forest naturalness can influence SOC content, and whether SOC content varies according to tree species and mixture, with the final goal to attempt to find a suitable stand composition which could replace the unnatural Norway spruce stands in the Czech Republic, especially in the context of global climate change, so as to fulfill at least a comparable carbon sequestration function.

\section{Material and methods}

\section{Description of study area}

In this study, the database of forest typology (at the Forest Management Institute FMI) was used. This data was acquired from monitoring plots, which were determined by the FMI.

The research included 81 monitoring plots established between 1960 to 2004 from the database of forest typology. The geographic location of each monitoring plot is defined. The database contains information on soil conditions of the site, including content of individual chemical elements and species composition of forest stands. The size of selected circular monitoring plots varied in the range of $400-500 \mathrm{~m}^{2}$.

The monitoring plots were mainly established in the eastern part of the Czech Republic, in the Jeseníky Mountains, the Drahanská vrchovina Upland, the Středomoravské Karpaty Mountains, the Kelečská pahorkatina Hills and partly in the Vý-

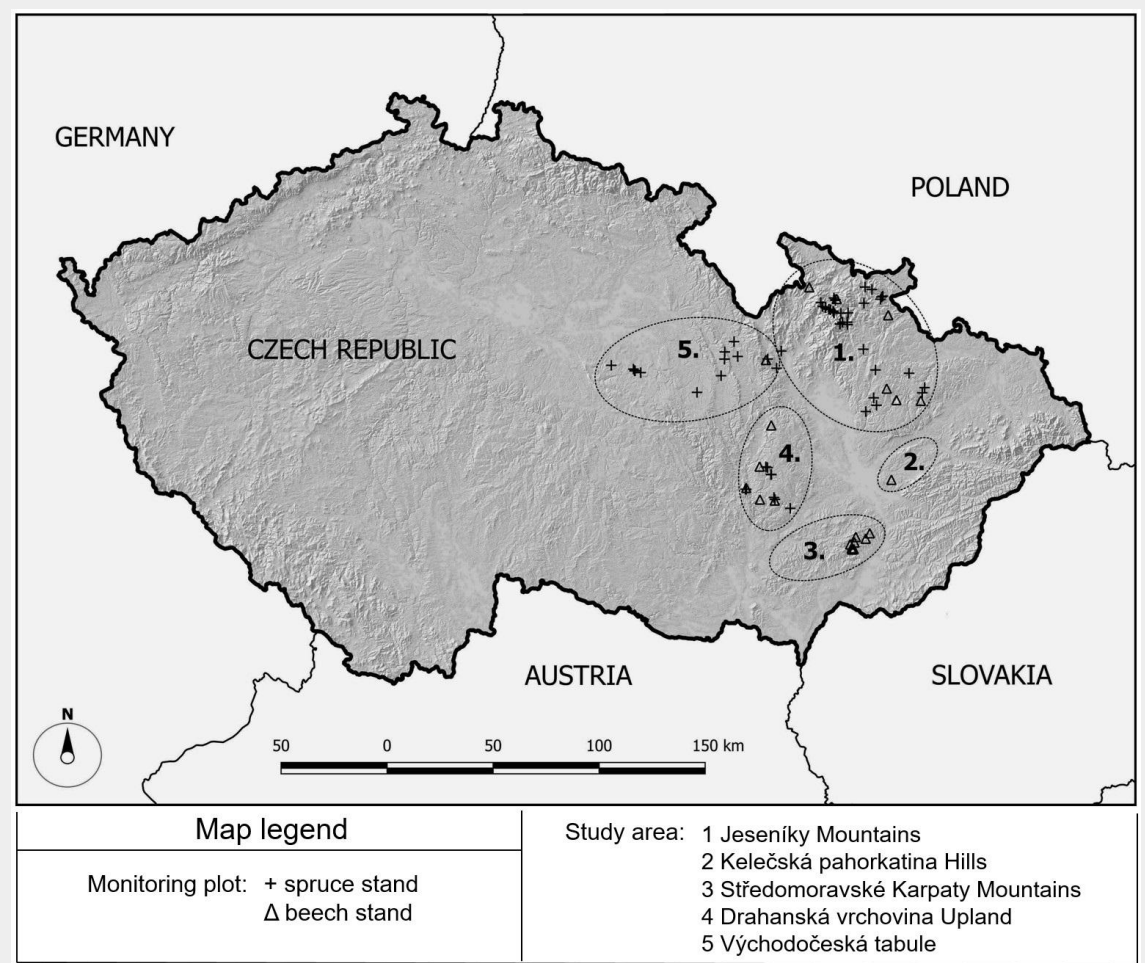

Fig. 1 - Location of the study area and monitoring plots. chodočeská tabule (Fig. 1). The selected set of plots occurs within an elevation range of 320-1318 $\mathrm{m}$ a.s.l. with an average annual air temperature of $2.1-8.1{ }^{\circ} \mathrm{C}$ and an average annual precipitation between 621 and 1106 $\mathrm{mm}$.

Soil conditions at the monitoring plots largely vary; according to the World Reference Base (WRB-IUSS Working Group 2014), they represent the soil groups of Cambisols, Podzols, Stagnosols, Luvisols and Leptosols. The dominant soil group in the selected set is Cambisols.

Soil samples were taken from the surface mineral soil horizon (the A horizon) in each soil pit. The thickness of surface mineral soil horizons ranged from 1 to $35 \mathrm{~cm}$ (with an arithmetic mean of $8 \mathrm{~cm}$ ). An organic horizon with thickness ranging 3-15 cm (mean $=7 \mathrm{~cm}$ ) was always present above the A horizon.

\section{Stand description}

The dataset of 81 monitoring plots included stands with $91-100 \%$ representation (share) of Norway spruce and European beech; these stands were marked as pure stands. In addition, stands with 50-90\% major (dominant) representation of spruce and beech were also present; these stands were marked as mixed stands. In these mixed stands, with dominance of spruce or beech, other species are present such as Silver fir (Abies alba Mill.), European larch (Larix decidua Mill.), Scots pine (Pinus sylvestris L.), Pedunculate oak (Quercus robur L.), Sessile oak (Quercus petraea Matt. Liebl.) and some other broadleaf species, either admixed or interspersed.

All the studied stands are located within an elevation range of 320-1318 m a.s.l. Norway spruce stands in the study area occur in the range of 325-1318 $\mathrm{m}$ a.s.l., but natural occurrence is in the range of $520-1318 \mathrm{~m}$ a.s.l. The occurrence of spruce below 520 $\mathrm{m}$ a.s.l. is considered unnatural in terms of site. Norway spruce occurs naturally on modal sites (without affecting the soil skeleton, flowing water and water in soil profile) from 520 to $730 \mathrm{~m}$ a.s.l. in an admixture of up to $20 \%$ along with beech, silver fir, and possibly other tree species. A natural mixture of spruce with beech and silver fir becomes prevalent in the range of 700-890 $\mathrm{m}$ a.s.l. Norway spruce begins to be naturally dominant in stands in the range 1010-1180 $\mathrm{m}$ a.s.l., culminating at 1170-1230 m. a.s.l. where the species becomes dominant in natural forest communities and is in optimal ecological conditions. Spruce growth is very limited by climatic conditions around $1318 \mathrm{~m}$ a.s.l. (flag forms of growth, dwarf solitaires, vegetative spread). The occurrence of European beech in stands of the study area was in the range of 320 to $880 \mathrm{~m}$ a.s.l., which is also its natural occurrence. It begins to prevail in the range of 450-560 $\mathrm{m}$ a.s.l., but occurs in admixture of up to $20 \%$ along with Sessile oak and European hornbeam. European beech is the naturally dominant tree 
species and occurs in optimal conditions (also in production optimum) in the range of 560-736 $\mathrm{m}$ a.s.l. Besides beech, Silver fir and Norway spruce also begin to occur naturally at an elevation of around $700 \mathrm{~m}$ a.s.l., and these tree species form a mixture from 700 to $900 \mathrm{~m}$ a.s.l. At higher elevations, the European beech recedes from the mixture into the understory, and the Norway spruce begins to dominate.

In the study area, there is no representation of unnatural stands of European beech. On the other hand, there is a heavy presence of unnatural stands of Norway spruce, especially unnatural pure stands, due to the massive establishment of monocultures. Therefore, there is probably no representation of natural mixed Norway spruce stands.

The age of the tree layer in the monitoring plots was in the range of 21 to 190 years. Stands included in this study are forests with applied forest management practices, which are conducted for economic purpose. All monitoring plots had been covered by forests for several generations; this is guaranteed by forest legislation, so there was no other way of using these plots in the past. The rotation period for Norway spruce is determined by law in the Czech Republic and is in the range of 130 years to physical age (physical rotation, physical age of Norway spruce fluctuates around 350 years) at higher elevation, thus in natural sites for this tree species. At other (lower) elevation levels the rotation period is in the range of 100 to 130 years, on modal sites the rotation period fluctuates around 110 years. The rotation period for European beech is in the range of 120 to 140 years; this range applies also on modal sites.

Definition and determination of degree of naturalness (forest naturalness)

Forest naturalness can be evaluated and expressed by various methods. Since we used the database of forest typology, the degree of naturalness was determined according to the Forest Management Institute method.

The naturalness of forest stands is expressed by the species composition of the stand. Natural species composition was reconstructed as the composition of natural forest communities. A natural forest is a forest with its original tree species, whose composition and proportion has been somewhat altered by man, but only to the extent that the forest self-regulating abilities have not been disrupted. The degree of naturalness is derived from the comparison of the actual species composition of each part of a stand with its natural potential composition (Macků 2012), which is derived from typological units. Macků (2012) states that the forest sites type is the basic unit for evaluation of the degree of naturalness. Forest sites type is a part of a forest which includes all original geobiocenosis with homogenous ecological or growth conditions and explicit amplitude of potential autochthonous and allochthonous tree species production. The forest type is characterized by a dominant species combination of phytocenosis, soil properties, habitat and potential yield class of the tree species. Forests types complex is a higher unit of system hierarchy (Typological System of the Forest Management Institute).

The degree of naturalness is a categorical variable taking values in the range of 0-6. The following degrees of naturalness are distinguished: o - unsuitable (introduced tree species); 1 - very low (mostly unsuitable composition); 2 - low (rather unsuitable composition); 3 - medial (culture forest - appropriate composition); 4 - high (mostly natural composition); 5 - very high (near natural composition); 6 - exceptional (natural composition). The adoption of such classification requires a sufficient number of samples (stands) per class to support statistical analysis. Therefore, the above classes were pooled in two groups: (i) natural vegetation (stands), with a degree of naturalness of 4-6; (ii) unnatural vegetation (stands), with a degree of naturalness of 1-3. This simplified classification was used in all further analyses.

\section{Soil sampling, determination of soil organic carbon (SOC) and chemical elements}

Soil samples were taken at each of the 81 monitoring plots during the growing season. Each soil sample was taken only once from a single soil pit (one soil pit in each monitoring plot) established in the central part of the monitoring plot. Each monitoring plot was established by the FMI as a representative site. Soil samples were taken from the A horizon by a FMI specialist with relevant experience of pedology, according to appropriate and current internal methodology at the time.

Soil samples were analysed in the laboratory at FMI in Brandýs nad Labem to determine the content of soil organic carbon (SOC) as well as the content of bound forms of oxides of selected chemical elements (iron: tFe; aluminium: tAl; calcium: $\mathrm{tCa}$; magnesium: $\mathrm{tMg}$; potassium: $\mathrm{tK}$; manganese: tMn; phosphorus: tP; nitrogen: $\mathrm{tN})$. Related variables, such as basic saturation (BS), $\mathrm{pH}\left(\mathrm{pH} / \mathrm{H}_{2} \mathrm{O}\right)$, and the ratio of carbon to nitrogen $(\mathrm{C} / \mathrm{N})$ were also determined. All soil samples were homogenized before the analysis.

For determination of SOC, the chromosulfuric compound oxidation method was used, which was accompanied by titration of hydroquinone (wet method - Nelson \& Sommers 1982). For a better comparison with related studies, $\mathrm{SOC}$ values were converted from units of $\%$ to units of $t$ ha $^{-1}$ for the surface mineral horizon, according to methodology proposed by Macků (Marek et al. 2011). The thickness of horizons in $\mathrm{cm}$, bulk density $\left(\mathrm{g} \mathrm{cm}^{-3}\right)$, and content of soil organic carbon SOC (\%) were then entered into the recalculation (of SOC in \% to SOC in $\left.t \mathrm{tha}^{-1}\right)$. Values of bulk density $\left(\mathrm{g} \mathrm{cm}^{-3}\right)$ were determined as bulk density reduced (dried at $105{ }^{\circ} \mathrm{C}$ to constant weight - gravimetric method). These values were part of the methodology by Macků in Marek et al. (2011), because for various combinations of forest vegetation zones and ecological series, specific bulk density for SOC in the surface mineral horizon is determined.

The determination of content of bound forms of oxides of selected chemical elements (tFe, tAl, tCa, tMg, tK, tMn, tP) and other soil parameters $(B S, p H, C / N)$ was performed according to FMI methodology at the FMI pedological laboratory in Brandýs nad Labem (FMI 2005). The content of the above elements was determined after leachate in $20 \% \mathrm{HCl}$ (see Tab. S1 in Supplementary material for details) and marked as "content of bound forms of oxides", according to FMI methodology and standard methods.

\section{Statistical analysis}

Statistical analysis was conducted using the software STATISTICA ${ }^{\otimes}$ v. 12 (StatSoft, Inc., Tulsa, OK, USA). Descriptive statistics for the analyzed variables are reported in Tab. S2 (Supplementary material). First, the dataset of 81 soil samples was analyzed. The relationships and dependencies between soil variables (SOC content; soil content of tFe, tAl, tCa, tMg, tK, tMn, tP, tN; $\mathrm{BS}, \mathrm{pH}$ and $\mathrm{C} / \mathrm{N}$ ratio) and a set of abiotic variables associated with the elevation gradient (average annual air temperature, average annual precipitation, duration of growing season, i.e., sum of days with temperature above $10{ }^{\circ} \mathrm{C}$ ) were analyzed by means of Spearman's correlation coefficients $(\alpha=0.05)$. For a better understanding of correlation structure among quantitative variables, PCA (Principal Component Analysis) was performed and the first two principal components were visualized in biplot (Fig. S1 in Supplementary material).

Based on the outputs from PCA and correlation analysis, the dataset of 81 monitoring plots was first divided into 2 groups, according to the degree of naturalness of stands: natural stands ( 35 plots) and unnatural stands (46 plots), following the methodology described above. These two groups were further subdivided into 5 partial datasets, according to the percentage representation of the dominant tree species in the stands and their degree of naturalness: (i) pure SP-na: natural stands with $91-100 \%$ of Norway spruce $(n=11)$; (ii) pure SP-un: unnatural stands with $91-100 \%$ of Norway spruce $(n=30)$; (iii) pure BE-na: natural stands with $91-100 \%$ of European beech ( $n=13$ ); (iv) mixed SP-un: unnatural stands with $50-90 \%$ of Norway spruce $(n=16) ;(v)$ mixed BE-na: natural stands with $50-90 \%$ of European beech $(n=11)$. Correlation analysis among the studied variables was performed independently for each of these partial datasets and a correlation matrix was obtained for each subset.

Spearman's or Pearson's correlation co- 

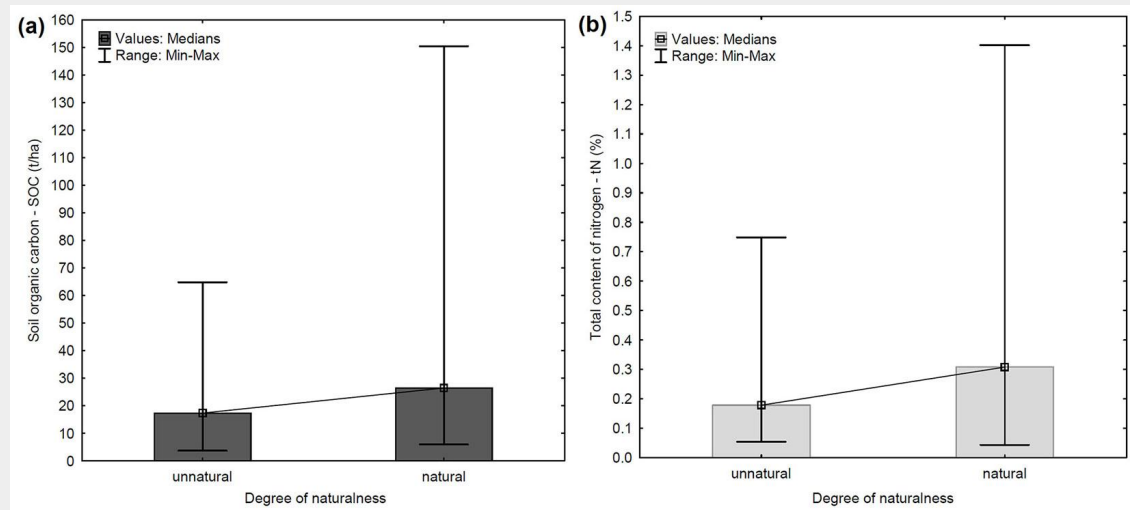

Fig. 2 - Comparison of $\mathrm{SOC}$ content (a) and $\mathrm{tN}$ content (b) in the mineral soil horizon between natural and unnatural stands at the 81 monitoring plots.

efficients were used, according to the data normality condition. To verify normality, the Shapiro-Wilk test was used. Non-normal distribution of datasets of pure stands has been demonstrated. For this reason, non-parametric methods and tests were preferred. On the other hand, normal distribution of datasets has been demonstrated in mixed stands. Levene's test was used to determine homogeneity of variance. To determine the outlier (extreme) values, the non-parametric Dean-Dixon test and the parametric Grubbs' test were used. Based on the results of the above tests, the Kruskal-Wallis test was conducted to determine the significance of differences between individual groups of variables in the datasets. The Kruskal-Wallis test was used in combination with the Mann-Whitney $U$ test in the case of non-normal distribution of data, while in the case of normal distribution of data the $t$-test was used. All tests were performed at $5 \%$ level of significance.

Description of the dataset made use of common descriptive statistics (median,
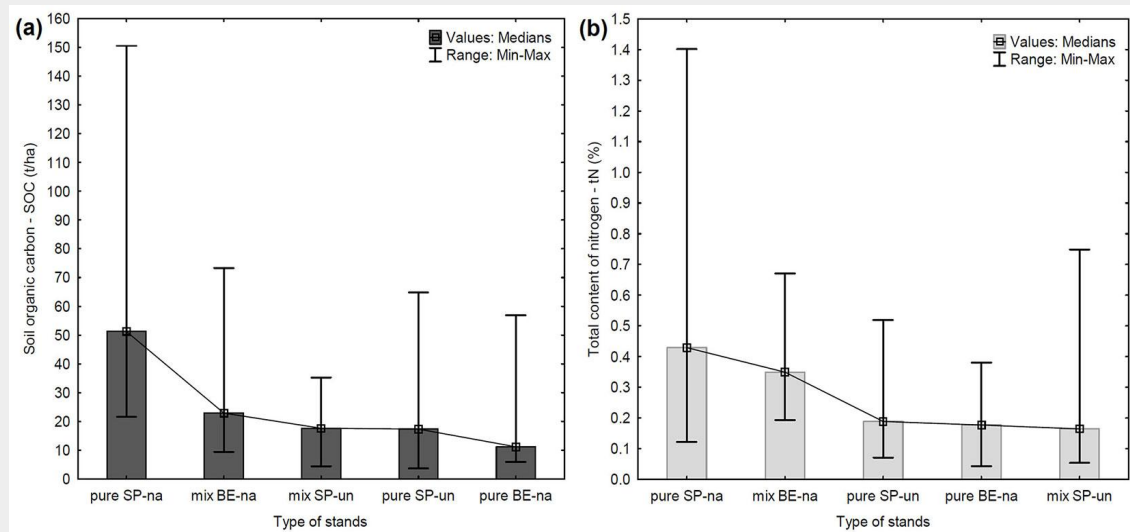

Fig. 3 - Comparison of $\mathrm{SOC}$ (a) and $\mathrm{tN}$ content (b) in mineral soil horizon in 5 groups of stands according to the representation of the dominant tree species. (pure SP-na): pure natural stands with 91-100\% representation of Norway spruce; (mix BE-na): mixed natural stands with 50-90\% representation of European beech; (mix SP-un): mixed unnatural stands with 50-90\% representation of spruce; (pure SP-un): pure unnatural stands with $91-100 \%$ representation of spruce; (pure BE-na): pure natural stands with $91-100 \%$ representation of beech. variables, a significant positive correlation of SOC with $\mathrm{tN}(\mathrm{R}=0.61 ; \mathrm{p}<0.01)$ was detected. The other chemical elements did not show any significant correlation with SOC content, except for phosphorus (tP) which was positively correlated with SOC $(R=0.32 ; p<0.05)$. A detailed analysis of the relationships among $\mathrm{SOC}, \mathrm{tN}$ and $\mathrm{tP}$ content and elevation showed mutual positive correlations (e.g., tP-tN: $\mathrm{R}=0.41, \mathrm{p}<$ 0.05; tP-elevation: $\mathrm{R}=0.47, \mathrm{p}<0.05-$ see also Fig. S2 in Supplementary material). Additionally, a positive correlation between SOC content and the degree of naturalness of stands was found.

The SOC content noticeably increases with increasing degree of naturalness of the analyzed stands $(R=0.22 ; p<0.05)$ using the dataset of 81 monitoring plots. Therefore, the content of SOC in the mineral soil horizon was compared between natural stands and unnatural stands (35 and 42 plots, respectively - Fig. 2a). A significantly higher content of SOC was detected in natural stands, ranging from 5.93 to $150.48 \mathrm{t} \mathrm{ha}^{-1}$, with a median of $26.46 \mathrm{t}$ $\mathrm{ha}^{-1}$, whilst in unnatural stands SOC content varied in the range 3.68-64.83 $\mathrm{t} \mathrm{ha}^{-1}$, with a median of $17.36 \mathrm{t} \mathrm{ha}^{-1}$. Content of $\mathrm{tN}$ was also significantly $(p<0.01)$ higher in natural stands, with a median value $0.31 \%$ (Fig. 2 b).

For more detailed results, differences between 5 groups of stands (according to the percentage representation of the dominant tree species and degree of naturalness of the stand) were found. The absolute highest content of SOC was found in pure SP-na (pure natural Norway spruce stands, $91-100 \%$ share) with a median of $51.27 \mathrm{t} \mathrm{ha}^{-1}$ and a remarkable variance due to the presence of several outlier values (Fig. 3a). The second highest content of SOC was observed in mix BE-na (natural mixed European beech stands, 50-90\%). On the other hand, the lowest content of SOC was also found in pure stands, but in pure BE-na (natural European beech stands, 91$100 \%$ ), with a median of 11.19 t ha $^{-1}$. Significant differences $(p<0.01)$ in SOC content between the 5 groups are reported in Tab. 1. Significant differences $(p<0.01)$ in SOC content were found between the groups of pure natural Norway spruce stands and pure natural European beech stands and between pure natural and pure unnatural Norway spruce stands (Tab. 2). The same comparison was made in mixed stands (Tab. 3), finding a significantly higher SOC content (median value: $22.90 \mathrm{t} \mathrm{ha}^{-1} ; \mathrm{p}<$ 0.05 ) in mixed BE-na (mixed natural European beech stands, 50-90\%).

We also found a significant positive correlation of SOC with $\mathrm{tN}$ in all pure stands (91$100 \%$ ), with SOC content increasing with increasing $\mathrm{tN}$ content. The correlation coefficient $(R)$ bewteen these variables was 0.73 in pure SP-na (pure natural Norway spruce stands, $91-100 \%$ representation), 0.59 in pure SP-un (pure unnatural Norway spruce stands, $91-100 \%$ ) and 0.71 in pure BE-na stands (pure natural European beech 
stands, 91-100\%). All the above correlations were significant at $p<0.05$. The highest content of $\mathrm{tN}$, with a median of $0.43 \%$, was detected in pure SP-na (pure natural Norway spruce stands, $91-100 \%$ - Fig. 3b). The content of $\mathrm{tN}$ observed in pure unnatural Norway spruce stands was similar to that recorded for pure natural European beech stands (0.19\% vs. $0.18 \%$, respectively). Significant differences in $\mathrm{tN}$ content between the 5 groups are displayed in Tab. 1, and between groups of pure stands in Tab. 2 . The trend of $\mathrm{tN}$ content is very similar to the trend of SOC content according to type of stand (Fig. 3a, Fig. 3b). Other chemical elements and related variables did not show any significant correlation with $\mathrm{SOC}$ content in all pure stands.

In mixed stands (50-90\% representation of the dominant species), a positive correlation between SOC and $\mathrm{tN}$ was found only in the case of natural beech stands (mixed BE-na: $r=0.63, p<0.05$ ), where the median value of $\mathrm{tN}$ was $0.35 \%$. For mixed unnatural spruce stands (mixed SP-un), the correlation was not significant. The difference in tN content between groups of mixed stands was significant $(\mathrm{p}<0.05)$, as well as the difference in SOC content (Tab. 3). In addition, a positive correlation between SOC content and tP $(r=0.69, p<0.05)$ was found only in natural mixed beech stands (mixed BE-na).

No further correlations or potential relationships of SOC were found with the other chemical elements under analysis. However, due to the presence of several outlier values, a connection between SOC and group of soil was revealed. In the dataset of 81 samples, the highest SOC content was observed in the Podzols group, with a median of $44.20 \mathrm{t} \mathrm{ha}^{-1}$ (Fig. 4a). Podzols also showed the highest variance in SOC content. The lowest SOC content was detected in the group "Other" (which includes Stagnosols, Leptosols, and Luvisols), where the median value was only $14.40 \mathrm{t} \mathrm{ha}^{-1}$. Significant differences in SOC content were observed between Podzols and Cambisols and between Podzols and the Other group (Tab. 4). The content of $t \mathrm{~N}$ was also compared among these groups of soil. The highest $\mathrm{tN}$ content was recorded in the Podzols group (median of $0.35 \%$ Fig. 4b), while the lowest was detected in the Other group (median value of $0.15 \%$ ). As observed for SOC, significant differences in $\mathrm{tN}$ content were found between the same groups of soil (Tab. 4). The trend of $\mathrm{tN}$ content is similar to the trend of SOC content for soil groups.

\section{Log-linear models}

A more complex assessment of factors influencing the SOC content is based on a linear model where log (SOC) was considered as a dependent variable. The (natural) logarithm was used to avoid problems caused by skewness of the distribution of SOC. Four different stand types were compared: the pure stands (91-100\% representation) of
Tab. 1 - Significant differences ( $\mathrm{p}$-values) in SOC and $\mathrm{tN}$ content between the 5 groups of stands after Kruskal-Wallis tests. (pure SP-na): pure natural stands with 91-100\% representation of Norway spruce; (mix BE-na): mixed natural stands with 50-90\% representation of European beech; (mix SP-un): mixed unnatural stands with 50-90\% representation of Norway spruce; (pure SP-un): pure unnatural stands with 91-100\% representation of Norway spruce; (pure BE-na): pure natural stands with 91-100\% representation of European beech; (ns): non-significant.

\begin{tabular}{|c|c|c|c|c|c|c|}
\hline Variable & Group & $\begin{array}{l}\text { pure } \\
\text { SP-na }\end{array}$ & $\begin{array}{l}\text { pure } \\
\text { SP-un }\end{array}$ & $\begin{array}{c}\text { pure } \\
\text { BE-na }\end{array}$ & $\begin{array}{l}\text { mixed } \\
\text { SP-un }\end{array}$ & $\begin{array}{l}\text { mixed } \\
B E-n a\end{array}$ \\
\hline \multirow{5}{*}{$\begin{array}{l}\text { Soil organic } \\
\text { carbon } \\
\left(\text { SOC, t ha }{ }^{-1}\right. \\
-p<0.01)\end{array}$} & pure SP-na & - & 0.000307 & 0.000299 & 0.000285 & ns \\
\hline & pure $S P$-un & 0.000307 & - & ns & ns & ns \\
\hline & pure BE-na & 0.000299 & ns & - & ns & ns \\
\hline & mixed SP-un & 0.000285 & ns & ns & - & ns \\
\hline & mixed $B E-n a$ & ns & ns & ns & ns & - \\
\hline \multirow{5}{*}{$\begin{array}{l}\text { Total nitrogen } \\
\text { content } \\
(\mathrm{tN}, \% \\
-\mathrm{p}<0.05)\end{array}$} & pure SP-na & - & 0.008479 & ns & 0.005001 & ns \\
\hline & pure $S P$-un & 0.008479 & - & ns & ns & 0.024039 \\
\hline & pure BE-na & ns & ns & - & ns & ns \\
\hline & mixed SP-un & 0.005001 & ns & ns & - & 0.013301 \\
\hline & mixed BE-na & ns & 0.024039 & ns & 0.013301 & - \\
\hline
\end{tabular}

Tab. 2 - Significant differences ( $p$-values) in SOC and $\mathrm{tN}$ content between the groups of pure stands according to Kruskal-Wallis tests. (pure SP-na): pure natural stands with $91-100 \%$ representation of Norway spruce; (pure SP-un): pure unnatural stands with $91-100 \%$ representation of Norway spruce; (pure BE-na): pure natural stands with 91-100\% representation of European beech.

\begin{tabular}{llccc}
\hline Variable & Group & pure SP-na & pure SP-un & pure BE-na \\
\hline $\begin{array}{l}\text { Soil organic carbon } \\
\left.\text { (SOC, } \mathrm{t} \mathrm{ha}{ }^{-1}-\mathrm{p}<0.01\right)\end{array}$ & pure SP-na & - & 0.000202 & 0.000182 \\
\cline { 2 - 5 } & pure SP-un & 0.000202 & - & - \\
\cline { 2 - 5 } & pure BE-na & 0.000182 & - & - \\
\hline $\begin{array}{l}\text { Total nitrogen content } \\
\text { (tN, \% - p < 0.05) }\end{array}$ & pure SP-na & - & 0.002051 & 0.019608 \\
& pure SP-un & 0.002051 & - & - \\
\cline { 2 - 5 } & pure BE-na & 0.019608 & - & - \\
\hline
\end{tabular}

Tab. 3 - Significant differences ( $\mathrm{p}$-values) in SOC and $\mathrm{tN}$ content between groups of mixed stands according to $t$-tests for independent samples. (mix BE-na): mixed natural stands with 50-90\% representation of European beech; (mix SP-un): mixed unnatural stands with $50-90 \%$ representation of Norway spruce.

\begin{tabular}{llcc}
\hline Variable & Group & mixed SP-un & mixed BE-na \\
\hline $\begin{array}{l}\text { Soil organic carbon } \\
\left.\text { (SOC, t ha }{ }^{-1}-\mathrm{p}<0.01\right)\end{array}$ & mixed SP-un & - & 0.020808 \\
\cline { 2 - 4 } $\begin{array}{l}\text { Total nitrogen content } \\
\text { (tN, } \%-\mathrm{p}<0.05 \text { ) }\end{array}$ & mixed SP-un & 0.020808 & - \\
\cline { 2 - 4 } & mixed BE-na & - & 0.020632 \\
\hline
\end{tabular}

Norway spruce and of European beech and given by the dominant tree species (Northe mixed stands (50-90\%) of spruce and of way spruce/European beech) coincides beech. It is worth noting that the factor with the categorised factor of naturalness

Tab. 4 - Significant differences ( $p$-values) in SOC and tN content between soil groups according to Kruskal-Wallis tests. (ns): non-significant.

\begin{tabular}{llccc}
\hline Variable & Group & Podzols & Cambisols & Other \\
\hline $\begin{array}{l}\text { Soil organic carbon } \\
\left.\text { (SOC, t ha }{ }^{-1}-\mathrm{p}<0.01\right)\end{array}$ & Podzols & - & 0.000419 & 0.002872 \\
& Cambisols & 0.000419 & - & $\mathrm{ns}$ \\
& Other & 0.002872 & $\mathrm{~ns}$ & - \\
\hline $\begin{array}{l}\text { Total nitrogen content } \\
(\mathrm{tN}, \%-\mathrm{p}<0.05)\end{array}$ & Podzols & - & 0.001920 & 0.001656 \\
& Cambisols & 0.001920 & - & $\mathrm{ns}$ \\
& Other & 0.001656 & $\mathrm{~ns}$ & - \\
\hline
\end{tabular}



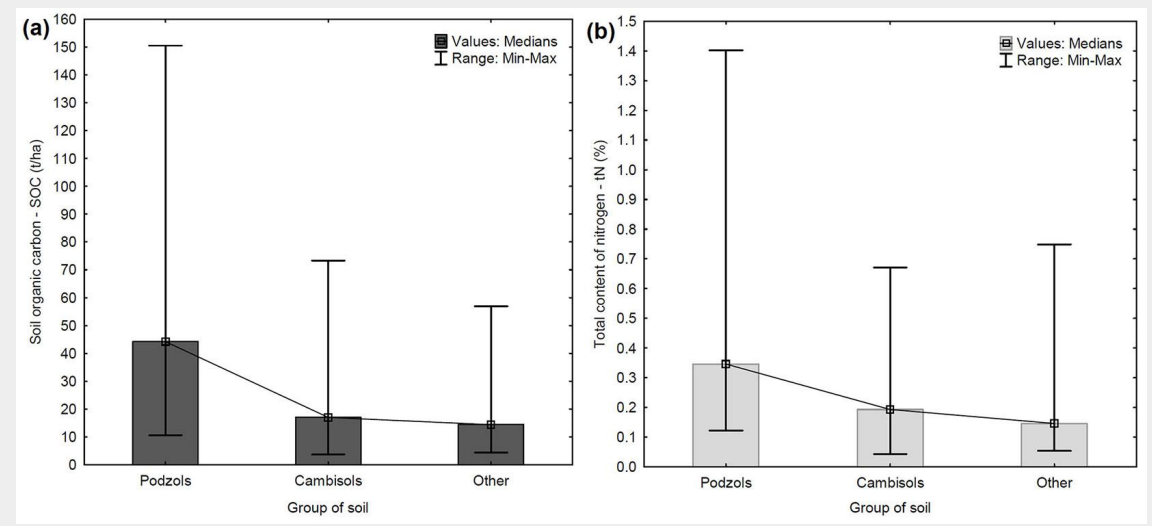

Fig. 4 - Comparison of $\mathrm{SOC}(\mathrm{a})$ and $\mathrm{tN}$ content (b) in mineral soil horizon between the different soil groups. (Other): includes Stagnosols, Leptosols, and Luvisols.

(unnatural/natural) in this case. The fifth group included in the original data set (i.e., the pure natural stands of Norway spruce) was excluded from this analysis because it differed significantly for several aspects from the remaining four groups (higher elevation and other abiotic factors, prevailing Podzols soil group). The remaining four groups did not differ significantly either in elevation or in soils, and, therefore, they were eligible for comparison.

The model revealed a significantly higher SOC content in the mixed European beech stands $(p=0.02)$. Their content of SOC was higher by $24 \%$ when compared with the three remaining groups. There were no significant differences between the remaining groups. The model also includes the factor of elevation. It was estimated that SOC content increases by $8.6 \%$ with a $100 \mathrm{~m}$ increase in elevation $(p=0.0006)$. For mixed European beech stands, the SOC content can be described as follows (eqn. 1):

$$
\log (S O C)=0.95+0.00083 \text { elevation }
$$

\section{while for the remaining stands (eqn. 2):}

$\log (S O C)=0.73+0.00083$ elevation

The effect of soil group was not significant. An analogous model can be fitted for $\mathrm{tN}$, resulting in a higher $\mathrm{tN}$ content for the European beech stands ( $p<0.0001)$. It is twice as high (100\% higher) when compared with the $\mathrm{tN}$ concentration in the remaining three groups, whose differences were not significant. The content of $\mathrm{tN}$ increases by $21.3 \%$ with a $100 \mathrm{~m}$ increase in elevation $(p<0.0001)$. For mixed European beech stands, the $\mathrm{tN}$ content can be described as follows (eqn. 3):

$\log (t N)=-2.61+0.00193$ elevation

and for the remaining stands (eqn. 4):

$\log (t N)=-2.80+0.00193$ elevation

The effect of soil group was not significant.

\section{Discussion}

Our results confirmed that elevation gradient, as a common factor underlying many abiotic variables, influences the content of $\mathrm{SOC}$ and $\mathrm{tN}$ in forest stands. With increasing elevation both $\mathrm{SOC}$ and $\mathrm{tN}$ contents increase. This trend has been previously reported by a number of studies (Chang et al. 2015, Tashi et al. 2016, Bojko et al. 2017, Bojko \& Kabala 2017, Hernandez et al. 2017, Wang et al. 2017; for $\mathrm{tN}$, Callesen et al. 2007). However, several studies also showed the opposite trend (Sheikh et al. 2009, Bangroo et al. 2017). According to several authors, high $\mathrm{SOC}$ and $\mathrm{tN}$ stocks have been found in mountain forests (at higher elevation) from tropical, to subtropical, to temperate regions (Bu et al. 2012, Chang et al. 2015, Yang et al. 2016). Higher $\mathrm{SOC}$ and $\mathrm{tN}$ content at higher elevations can be explained by the lower temperature and higher precipitation, which reduce the decomposition rate, as well as by the higher proportion of fine-root biomass and the high root:shoot ratio of trees, which maximize the nutrient uptake when nutrient availability is limited as a result of lower decomposition (Soethe et al. 2006, Chang et al. 2015).

In this study, we also found that $\mathrm{tN}$ content is associated with SOC content. Scientific literature has long discussed the effect of nitrogen deposition on carbon content (SOC storage) in forest soil, but the results are uncertain, although the prevailing opinion in scientific discussion is of a positive relationship between them (Chen et al. 2017, Tipping et al. 2017, Oulehle et al. 2018). Our results showed that $\mathrm{t} N$ content is higher in stands with high SOC content, and a positive correlation between them has been demonstrated. Based on this finding, it is possible to hypothesize the positive effect of $\mathrm{tN}$ on SOC content and carbon sequestration. According to meta-analysis by Janssens et al. (2010), it can be assumed that nitrogen deposition impedes organic matter decomposition, thus favoring carbon sequestration, in temperate forest soils where nitrogen does not limit microbial growth. However, the role of nitro- gen deposition in increasing net primary production (NPP), and the subsequent carbon sequestration in European forests, is still a subject of debate with contrasting scientific opinions (Magnani et al. 2007, De Vries et al. 2008).

The relationship between other chemical elements (content of bound forms of oxides of $\mathrm{Fe}, \mathrm{Al}, \mathrm{Ca}, \mathrm{Mg}, \mathrm{K}$ and $\mathrm{Mn}$ ) or related variables $(\mathrm{BS}, \mathrm{pH}, \mathrm{C} / \mathrm{N})$ and $\mathrm{SOC}$ content were also considered in this study. None of these variables (except phosphorous) affected the SOC content in the studied stands (see Fig. S1 in Supplementary material). The mutual positive correlation of $\mathrm{SOC}, \mathrm{tN}$, and $\mathrm{tP}$ with elevation in our dataset of 81 monitoring plots allows to speculate the potential synergistic positive effect of these variables on carbon sequestration. However, in order to confirm this hypothesis, it will be necessary to repeat similar analyses on larger datasets.

We observed a significant relationship between SOC content and the degree of naturalness in the studied stands. Moreover, a higher content of SOC and $t N$ was recorded in the soil of natural stands (Fig. 2a, Fig. 2b). The relationship between forest naturalness and SOC content is not sufficiently elucidated. Forest naturalness, its assessment and use as a criterion for forest management, is discussed in many publications (Brumelis et al. 2011, McRoberts et al. 2012, Zimmermann et al. 2015), but no studies focused on the influence of forest naturalness on the ability to store soil organic carbon. To throw light on this topic, we divided the 81 monitoring plots into 5 groups, according to forest naturalness and predominant tree species. However, there was an unequal number of samples in each group due to the limited number of plots analyzed. Indeed, only a small number of natural pure Norway spruce stands are present in the studied area, due to limited extension of mountain forests. On the other hand, the study area has a significant representation of unnatural Norway spruce stands. It should also be noted that samples from unnatural pure European beech stands, natural mixed Norway spruce stands and unnatural mixed European beech stands were not present in the dataset from the study area.

Our results support the evidence that more SOC is stored under coniferous trees than broadleaf trees (Kern et al. 2016, Bojko \& Kabala 2017, Park \& Ro 2018). Higher $\mathrm{SOC}$ and $\mathrm{tN}$ content were found in natural pure Norway spruce stands than in natural pure European beech stands. Oulehle et al. (2018) also proved a higher content of nitrogen under spruce stands than beech stands. The higher content of SOC and $\mathrm{tN}$ directly relates to differences in elevation and the associated occurrence of a group of soils on which the stands naturally grow in the study area. Indeed, the natural pure Norway spruce stands occur from 1010 to $1318 \mathrm{~m}$ a.s.l. (with a median of $1180 \mathrm{~m}$ a.s.l.) where the dominant group of soils is Pod- 


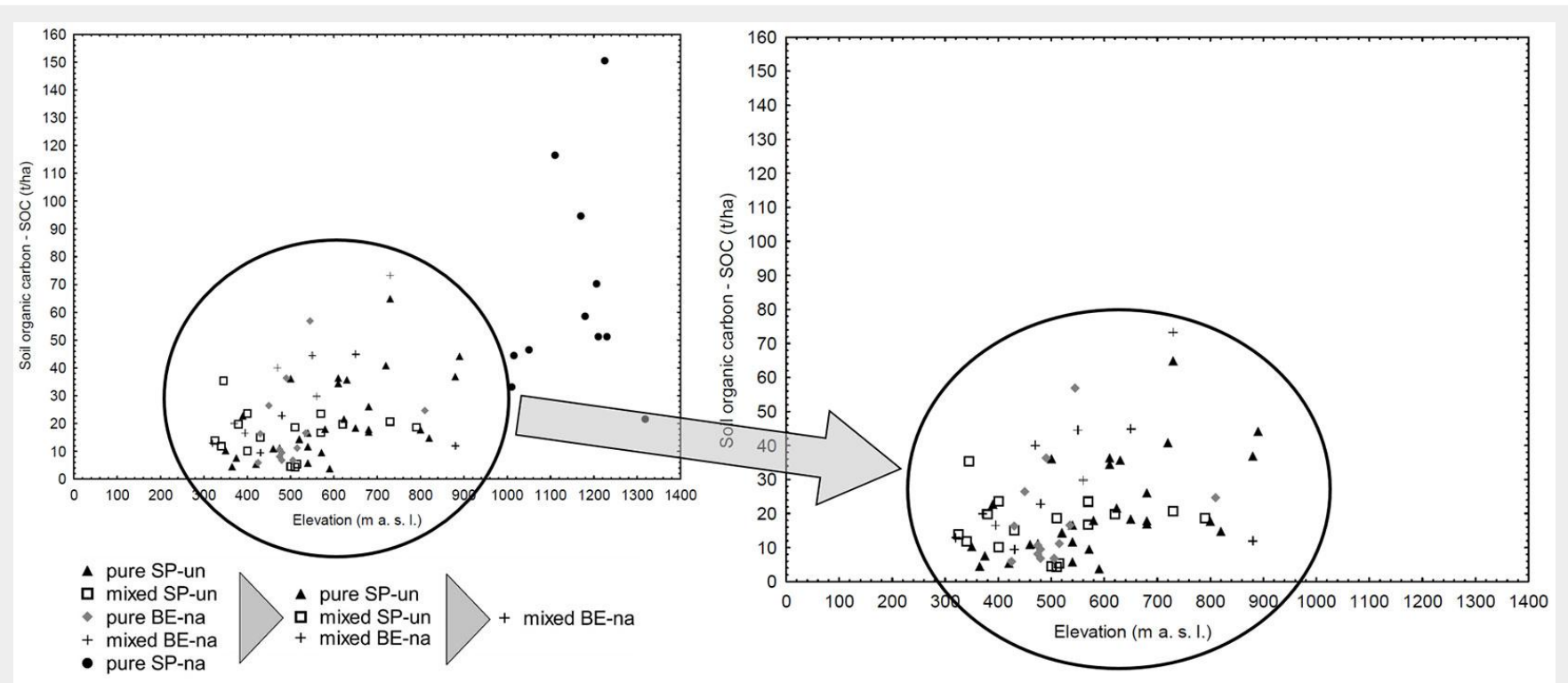

Fig. 5 - Dual chart of the 81 individual stands divided in 5 groups according to elevation and SOC content. In the right panel (detail), the black circle highlights the range of elevation and SOC content where unnatural spruce stands could be replaced by mixed nat ural beech stands (see text). Stands belonging to the same group, according to dominant tree species and degree of naturalness, are indicated by the same symbol. (pure SP-na): pure natural stands with 91-100\% representation of Norway spruce; (mix BE-na): mixed natural stands with 50-90\% representation of European beech; (mix SP-un): mixed unnatural stands with 50-90\% representation of Norway spruce; (pure SP-un): pure unnatural stands with 91-100\% representation of Norway spruce; (pure BE-na): pure natural stands with $91-100 \%$ representation of European beech.

zols; whereas the natural pure European beech stands occur from 425 to $810 \mathrm{~m}$ a.s.l. (with a median of $480 \mathrm{~m}$ a.s.l.) where the dominant group of soils is Cambisols. Natural pure Norway spruce stands play a very important and irreplaceable role in sequestration of SOC. Of all the observed stands, they showed the highest SOC content and also the highest $\mathrm{tN}$ content (Fig. 3a, Fig. 3b).

In this study, the SOC (and $\mathrm{tN}$ ) content was higher in natural mixed European beech stands, compared with unnatural mixed Norway spruce stands or unnatural pure Norway spruce stands (Fig. 3a, Fig. $3 b)$. These stands occur at comparable elevations (natural mixed European beech: 320-880 m a.s.l.; unnatural mixed Norway spruce: $325-790 \mathrm{~m}$ a.s.l.; unnatural pure Norway spruce: $350-890 \mathrm{~m}$ a.s.l.) where the common dominant soil group is Cambisols (see also Fig. S3 in Supplementary material). These stands differ in their forest naturalness, so it can be assumed that forest naturalness is, for these stands, an important parameter in relation to SOC sequestration. Moreover, we found that natural mixed European beech stands had a higher SOC content than unnatural mixed and pure Norway spruce stands. Similar results were also reported by Kern et al. (2016) and Dawud et al. (2017). Based on the above evidence, it would be advisable to consider establishing natural mixed European beech stands in the considered elevation belt, thus replacing existing unnatural Norway spruce stands (Fig. 5). In the context of increasing problems of dieback of Norway spruce stands grown on unnatural sites in the Czech Republic, and of global climate change (Klimo et al. 2000, Kolström et al. 2012, Neuner \& Knoke 2017), it is appropriate to consider the function of sequestration of carbon in the restoration and conversion of these stands. According to Andivia Muñoz et al. (2015) an admixture of individual European beech and Norway spruce trees may lead to a transfer of SOC from the forest floor to the better protected mineral soil layer, which might be beneficial for long-term SOC sequestration. In this study, attention has also been paid to the relationship between $\mathrm{SOC}$ and $\mathrm{tN}$ content and soil group and elevation (Batjes 2014, Bojko \& Kabala 2017). Among all the soil groups, the highest content of SOC and $\mathrm{tN}$ was observed in the Leptosols, though this results was based on two samples only. Therefore, further research with a higher number of samples for this soil type (soil group) are needed. Due to the uneven and low number of samples in some soil groups, the soil groups were divided into 3 groups (Podzols, Cambisols and Other). The highest $\mathrm{SOC}$ and $\mathrm{tN}$ content was demonstrated in the Podzols soil group (Fig. 4a, Fig. 4b), which included all extreme values (outliers) of SOC. After finding that Podzols contain significantly higher content of SOC in upper soil horizons, these samples were intentionally kept in the dataset. Strand et al. (2016) stated that Podzolic soils have a larger fraction of profile $\mathrm{C}$ in mineral soil (about 60\%) compared with other mineral soils (Regosolic: 36\%; Gleysolic: 41\%), and that tN content is similar. Bojko \& Kabala (2017) also found the highest content of SOC in the Podzols group and also demonstrated a trend in $\mathrm{SOC}$ content Luvisols < Cam- bisols < Podzols which is very similar to our results (Fig. 4a). In the context of Czech forests, certain soil types (soil groups) predominantly occur at certain elevations (for example Podzols prevail at high altitude Fig. S3 in Supplementary material). These evidence supports the hypothesis that natural pure Norway spruce stands growing in natural sites and conditions can indeed fulfill the indispensable function of SOC sequestration.

\section{Conclusion}

Our results show that elevation has a positive relationship with $\mathrm{SOC}$ and $\mathrm{tN}$ content in the surface mineral horizon of Norway spruce and European beech stands. Of the studied chemical elements and related variables, only a close positive relationship between SOC and $\mathrm{tN}$ content was observed. A positive relationship of forest naturalness and SOC content was also demonstrated, with a higher SOC content in natural stands compared with unnatural stands. The comparison of soil samples between tree species (spruce vs. beech) and stand types (pure vs. mixed) revealed the highest SOC content in pure natural Norway spruce stands. We conclude that these stands can perform a very important and irreplaceable function in the sequestration of SOC. The second highest SOC content was found in mixed natural European beech stands, which was higher than that observed for mixed unnatural Norway spruce stands and pure unnatural Norway spruce stands. Therefore, regarding carbon sequestion in the soil, mixed European beech stands could be considered suitable for the replacement of Norway spruce stands grow- 
ing at unnatural sites, especially in the context of global climate change and current spruce dieback.

Changing forest management to nearnatural forms and respecting models of potential natural vegetation seems to be a suitable way of fulfilling the carbon sequestration function, especially under the anticipated climate change. Further research should be done on larger datasets aimed at finding other suitable stand types (including other tree species and admixtures) which can effectively and successfully perform the carbon sequestration functions ("carbon service").

\section{Acknowledgements}

This work was supported by the Technology Agency of the Czech Republic (project No. SS02030018). The authors wish to thank four anonymous reviewers for their valuable and insightful comments which significantly improved the original manuscript. The authors and the Palacký University thank the Forest Management Institute for providing data.

\section{References}

Ammer C, Bickel E, Kölling C (2008). Converting Norway spruce stands with beech - a review of arguments and techniques. Austrian Journal of Forest Science 125: 3-26. [online] URL: http:// www.cabdirect.org/cabdirect/abstract/200932 90174

Andivia Muñoz E, Rolo V, Jonard M, Formánek P, Ponetta Q (2015). Effect of species composition on carbon and nitrogen stocks in forest floor and mineral soil in Norway spruce and European beech mixed forests. In: "EGU General Assembly 2015”. Vienna (Austria) 12-17 Apr 2015. Geophysical Research Abstracts, vol. 2015, pp. 4901. [online] URL: http://hdl.handle.net/2078. $1 / 162993$

Bangroo SA, Najar GR, Rasool A (2017). Effect of altitude and aspect on soil organic carbon and nitrogen stocks in the Himalayan Mawer forest range. Catena 158: 63-68. - doi: 10.1016/j.catena. 2017.06.017

Batjes NH (2014). Total carbon and nitrogen in the soils of the world. European Journal of Soil Science 65: 10-21. - doi: 10.1111/ejss.12114_2

Bojko O, Kabala C (2017). Organic carbon pools in mountain soils - Sources of variability and predicted changes in relation to climate and land use changes. Catena 149: 209-220. - doi: 10.1016/j.catena.2016.09.022

Bojko O, Kabala C, Mendyk L, Markiewicz M, Pagacz-Kostrzewa M, Glina B (2017). Labile and stabile soil organic carbon fractions in surface horizons of mountain soils - relationships with vegetation and altitude. Journal of Mountain Science 14: 2391-2405. - doi: 10.1007/s11629-0174449-1

Bremner JM (1960). Determination of nitrogen in soil by Kjeldahl method. Journal of Agriculture Science 55: 11-33. - doi: 10.1017/So02185960 0021572

Brumelis G, Jonsson BG, Kouki J, Kuuluvainen T, Shorohova E (2011). Forest naturalness in northern Europe: perspectives on processes, structures and species diversity. Silva Fennica 45: 807-821. - doi: 10.14214/sf.446

Bu X, Ruan H, Wang L, Ma W, Ding J, Yu X (2012). Soil organic matter in density fractions as related to vegetation changes along an altitude gradient in the Wuyi Mountains, southeastern China. Applied Soil Ecology 52: 42-47. - doi: 10.1016/j.apsoil.2011.10.005

Callesen I, Raulund-Rasmussen K, Westman CJ, Tau-Strand L (2007). Nitrogen pools and C:N ratios in well-drained nordic forest soils related to climate and soil texture. Boreal Environment Research 12: 681-692. [online] URL: http:// helda.helsinki.fi/bitstream/handle/10138/235558 /ber12-6-681.pdf

Čermák P, Jankovský L, Cudlín P (2004). Risk evaluation of the climatic change impact on secondary Norway spruce stands as exemplified by the Krtiny Training Forest Enterprise. Journal of Forest Science 50: 256-262. - doi: 10.17221/4623-JFS

Čermák P, Holuša O (2010). Forestry adaptation measures at the decline of Norway spruce (Picea abies Karst.) stands as exemplified by the Silesian Beskids, CR. Acta Universitatis Agriculturae et Silviculturae Mendelianae Brunensis 59: 293-302. - doi: 10.11118/actaun201159010293

Čermák P, Mikita T, Kadavý J (2017). Budoucnost hospodaření se smrkem $v$ období předpokládaných klimatických změn [The future of spruce management during the anticipated climate change]. Lesnická práce [Forestry work] 96: 13-15. [in Czech]

Chang R, Wang G, Fei R, Yang Y, Ji L, Fan J (2015). Altitudinal change in distribution of soil carbon and nitrogen in Tibetan montane forests. Soil Science Society of America Journal 79: 14551469. - doi: 10.2136/sssaj2015.02.0055

Chen ZJ, Geng SC, Zhang JH, Setälä H, Gu Y, Wang F, Zhang X, Wang XX, Han SJ (2017). Addition of nitrogen enhances stability of soil organic matter in a temperate forest. European Journal of Soil Science 68: 189-199. - doi: 10.1111/ ejss.12404

Ciais P, Schelhaas MJ, Zaehle S, Piao SL, Cescatti A, Liski J, Luyssaert S, Le Maire G, Schulze ED, Bouriaud O, Freibauer A, Valentini R, Nabuurs GJ (2008). Carbon accumulation in European forests. Nature Geosciences 1: 425-429. - doi: 10.1038/ngeo233

Czech Ministry of Agriculture (2018). Zpráva o stavu lesa a lesního hospodářství České republiky v roce 2017 [Report on the state of forests and forest management of the Czech Republic in 2017]. Ministry of Agriculture of the Czech Republic, Prague, Czech Republic. pp. 118. [in Czech] [online] URL: http://www.uhul.cz/ima ges/ke_stazeni/zelenazprava/ZZ_2017.pdf

Dawud SM, Vesterdal L, Raulund-Rasmussen $\mathrm{K}$ (2017). Mixed-species effects on soil $C$ and $N$ stocks, $\mathrm{C} / \mathrm{N}$ ratio and $\mathrm{pH}$ using a transboundary approach in adjacent common garden Douglasfir and beech stands. Forests 8: 95. - doi: 10.339 o/f8040095

De Vries W, Solberg S, Dobbertin M, Sterba H, Laubhahn D, Reinds GJ, Nabuurs G-J, Gundersen $P$, Sutton MA (2008). Ecologically implausible carbon response? Nature 451 (7180): E1-E3. doi: $10.1038 /$ nature 6579

FMI (2005). Standard operational procedures of pedological laboratory (SOP). Internal publica- tion, Forest Management Institute, Brandýs nad Labem, Czech Republic.

Hernandez L, Alberdi I, Jandl R, Blujdea VNB, Lehtonen A, Kriiska K, Alberdi I, Adermann V, Cañellas I, Marin G, Moreno-Fernández D, Ostonen I, Varik M, Didion M (2017). Towards complete and harmonized assessment of soil carbon stocks and balance in forests: the ability of the Yassoo7 model across a wide gradient of climatic and forest conditions in Europe. Science of The Total Environment 599: 1171-1180. doi: 10.1016/j.scitotenv.2017.03.298

Hlásný T, Pajtík J, Balázs B, Barcza Z, Turčáni $M$, Fabrika M, Sedmák R, Churkina G (2011). Climate change impacts on growth and carbon balance of forests in Central Europe. Climate Research 47: 219-236. - doi: 10.3354/cr01024 ISO (1995). ISO 11261:1995 Soil quality - Determination of total nitrogen - Modified Kjeldahl method. International Organisation for Standardization, Czech version norm CSN ISO 11261 (836415), Office for Technical Standardization, Metrology and State Testing, Prague, Czech Republic, pp. 4.

Jandl $R$, Lindner $M$, Vesterdal L, Bauwens $B$, Baritz R, Hagedorn F, Johnson DW, Minkkinen K, Byrne KA (2007). How strongly can forest management influence soil carbon sequestration? Geoderma 137: 253-268. - doi: 10.1016/j.geo derma.2006.09.003

Janssens IA, Dieleman W, Luyssaert S, Subke J-A, Reichstein M, Ceulemans R, Ciais P, Dolman AJ, Grace J, Matteucci G, Papale D, Piao SL, Schulze E-D, Tang J, Law BE (2010). Reduction of forest soil respiration in response to nitrogen deposition. Nature Geoscience 3: 315-322. - doi: 10.103 8/ngeo844

Jonard M, Nicolas M, Caignet I, Ponette Q, Saenger A, Coomes DA (2017). Forest soils in France are sequestering substantial amounts of carbon. Science of The Total Environment 574: 616-628. - doi: 10.1016/j.scitotenv.2016.09.028

Kern VN, Cremer M, Prietzel J (2016). Soil organic carbon and nitrogen stocks under pure and mixed stands of European beech, Douglas fir and Norway spruce. Forest Ecology and Management 367: 30-40. - doi: 10.1016/j.foreco.2016. 02.020

Klimo E, Kulhavý J, Hager H (2000). Spruce monocultures in Central Europe: problems and prospects. EFI Proceedings no. 33, Joensuu, Finland, pp. 209.

Kolström $M$, Lindner $M$, Vilén $T$, Maroschek $M$, Seidl R, Lexer MJ, Netherer S, Kremer A, Delzon S, Barbati A, Marchetti M, Corona P (2012). Reviewing the science and implementation of climate change adaptation measures in European forestry. Forests 2: 961-982. - doi: $10.3390 /$ f2040961

Lorenz K, Lal R (2010). Carbon sequestration in forest ecosystems. Springer Netherlands, Dordrecht, Netherlands, pp. 279. - doi: 10.1007/97890-481-3266-9_6

Löf $M$, Bergquist J, Brunet J, Karlsson M, Welander NT (2010). Conversion of Norway spruce stands to broadleaved woodland-regeneration systems, fencing and performance of planted seedlings. Ecological Bulletins 53: 165-174. [online] URL: http://www.jstor.org/stable/414420 28 
Macků J (2012). Methodology for establishing the degree of naturalness of forest stands. Acta Universitatis Agriculturae et Silviculturae Mendelianae Brunensis 18: 161-165.

Magnani $F$, Mencuccini $M$, Borghetti $M$, Berbigier $\mathrm{P}$, Berninger F, Delzon S, Grelle A, Hari P, Jarvis $P G$, Kolari $P$, Kowalski AS, Lankreijer $H$, Law BE, Lindroth A, Loustau D, Manca G, Moncrieff JB, Rayment $M$, Tedeschi V, Valentini R, Grace J (2007). The human footprint in the carbon cycle of temperate and boreal forests. Nature 447: 848-852. - doi: 10.1038/nature05847 Marek MV, Ač A, Apltauer J, Bodlák L, Burešová R, Cienciala E, Cudlín P, Cudlínová E, Czerny R, Cíková $H$, Dubrovský $M$, Dušek J, Exnerová $Z$, Havránková K, Henlík V, Janderková J, Janouš D, Lapka M, Macků J, Matějka K, Pavelka M, Pechal L, Pokorný J, Pokorný R, Schneider J, Stará L, Středa T, Taufarová K, Tomášková I, Urban O, Vyskot I, Zatloukal V, Zemek F, Zitová M (2011). Uhlík v ekosystémech České republiky v měnícím se klimatu [Carbon in ecosystems of Czech Republic in changing climate] ( $1^{\text {st }}$ edn). Academia, Prague, Czech Republic, pp. 255. [in Czech]

McRoberts RE, Winter S, Chirici G, LaPoint E (2012). Assessing forest naturalness. Forest Science 58: 294-309. - doi: 10.5849/forsci.10-075 Nelson DW, Sommers LE (1982). Total carbon, organic carbon, and organic matter. In: "Methods of Soil Analysis: Part 2 Chemical and Microbiological Properties" (Page AL, Miller $\mathrm{RH}$, Keeney DR eds). American Society of Agron omy, Soil Science Society of America, Academic Press, Madison, WI, USA, pp. 539-580.

Neuner S, Knoke T (2017). Economic consequences of altered survival of mixed or pure Norway spruce under a dryer and warmer climate. Climate Change 140: 519-531. - doi: 10.100 7/s10584-016-1891-y

Oulehle F, Tahovská K, Chuman T, Evans CHD, Hruška J, Ruek M, Bárta J (2018). Comparison of the impacts of acid and nitrogen additions on carbon fluxes in European conifer and broadleaf forests. Environmental Pollution 238: 884-893. - doi: 10.1016/j.envpol.2018.03.081

Park JS, Ro HM (2018). Temporal variations in soil profile carbon and nitrogen during three consecutive years of $\mathrm{N}-15$ deposition in temper- ate oak and pine forest stands. Forests 9: 338. doi: $10.3390 / f 9060338$

Sheikh MA, Kumar M, Bussmann RW (2009). Altitudinal variation in soil organic carbon stock in coniferous subtropical and broadleaf temperate forests in Garhwal Himalaya. Carbon Balance and Management 4 (1): 151. - doi: 10.1186/1 750-0680-4-6

Soethe N, Lehmann J, Engels C (2006). The vertical pattern of rooting and nutrient uptake at different altitudes of a South Ecuadorian montane forest. Plant and Soil 286: 287-299. - doi: 10.1007/s11104-006-9044-0

Standovár T, Kenderes K (2003). A review on natural stand dynamics in beechwoods of east central Europe. Ecology and Environmental Research 1: 19-46. - doi: 10.15666/aeer/01019046 Strand NT, Callesen I, Dalsgaard L, De Wit HA (2016). Carbon and nitrogen stocks in Norwegian forest soils - The importance of soil formation, climate, and vegetation type for organic matter accumulation. Canadian Journal of Forest Research 46 (12): 1459-1473. - doi: 10.1139/ cjfr-2015-0467

Tashi S, Singh B, Keitel C, Adams M (2016). Soil carbon and nitrogen stocks in forests along an altitudinal gradient in the eastern Himalayas and a meta-analysis of global data. Global Change Biology 22: 2255-2268. - doi: 10.1111/gcb. 13234

Tipping E, Davies JAC, Henrys PA, Kirk GJD, Lilly A, Dragosits U, Carnell EJ, Dore AJ, Sutton MA, Tomlinson SJ (2017). Long-term increases in soil carbon due to ecosystem fertilization by atmospheric nitrogen deposition demonstrated by regional scale modelling and observations. Scientific Reports 7 (1): 376. - doi: 10.1038/s41598017-02002-w

Vesterdal L, Clarke N, Sigurdsson BD, Gundersen $P$ (2013). Do tree species influence soil carbon stocks in temperate and boreal forests? Forest Ecology and Management 309: 4-18. - doi: 10.1016/j.foreco.2013.01.017

Wang S, Zhuang Q, Wanga Q, Jina X, Han C (2017). Mapping stocks of soil organic carbon and soil total nitrogen in Liaoning Province of China. Geoderma 305: 250-263. - doi: 10.1016/j. geoderma.2017.05.048
WRB-IUSS Working Group (2014). World reference base for soil resources 2014, update 2015. World Soil Resources Reports no. 106, Food and Agriculture Organization, Rome, Italy, pp. 203. [online] URL: http://www.fao.org/3/i379 4en/l3794en.pdf

Yang R, Zhang G, Liu F, Lu Y, Yang F, Yang F, Yang M, Zhao Y-G, Li D-CH (2016). Comparison of boosted regression tree and random forest models for mapping topsoil organic carbon concentration in an alpine ecosystem. Ecological Indicators 60: 870-878. - doi: 10.1016/j.eco lind.2015.08.036

Zimmermann J, Hauck M, Dulamsuren C, Leuschner C (2015). Climate warming related growth decline affects Fagus sylvatica, but not other broad-leaved tree species in Central European mixed forests. Plant Ecology 18: 560-572. doi: 10.1007/s10021-015-9849-x

\section{Supplementary Material}

Tab. S1 - The methods used for determination of content of bound forms of oxides of chemical elements ( $t F e, t A l, t C a, t M g$, $\mathrm{tK}, \mathrm{tMn}, \mathrm{tP})$ and other parameters (BS, $\mathrm{pH}$, $\mathrm{C} / \mathrm{N}$ ), according to $\mathrm{FMI}$ methodology at the FMI pedological laboratory in Brandýs nad Labem (FMI 2005).

Tab. S2 - Descriptive statistics of a dataset of 81 samples for all input variables.

Fig. S1 - Biplot - projection of input variables.

Fig. S2 - Diagram of mutual positive correlations among elevation, content of bound forms of oxides of phosphorus (tP), total content of nitrogen ( $t N)$ and soil organic carbon (SOC).

Fig. S3 - Distribution of samples with information about the SOC content attributed to represented soil groups at different elevations.

Link: Horvath_3654@supplo01.pdf 